\title{
Profil dan Keragaman Ayam Kub yang Dipelihara Oleh RTM Peternak dalam Program Bekerja di Kabupaten Indramayu
}

\section{Profile and Diversity of KUB Chicken Raised by Farmer Households in Bekerja Program in Indramayu District}

\section{Ganjar Hadiyanto Pratomo}

Pusat Penelitian dan Pengembangan Peternakan, Bogor

\section{Article history \\ Received: Aug 29, 2020; \\ Accepted: May 23, 2021 \\ * Corresponding author: \\ E-mail: \\ ganjar_pratomo@yahoo.com \\ DOI: \\ 10.46549/jipvet.v11i3.143

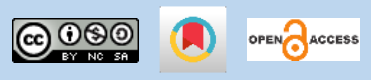

\begin{abstract}
The aim of this study was to determine the diversity of KUB chickens raised by farmer households in Indramayu Regency in the implementation of the 2019 BEKERJA program. The BEKERJA program is carried out in 8.189 farmer households by providing 50 DOC, chicken feed during 5 weeks, maintenance support facilities include feed tray, drinking bottles, brooder cages, cables, lights, and cage subsidy for 4 weeks chickens. The parameters observed were the number of chicken mortality, age of first egg laying and the number of egg production for the first time. The observations showed that the mortality of KUB chickens increased at 3 months of raised, which was caused by the sale and slaughter of chickens and the mortality of chickens due to improper raise management. Hens that lay eggs early in the District of Anjatan and District of Bongas 7.066 and 1.041 , respectively. The results of the study showed that there was diversity at the beginning of egg-laying chicken due to improper feeding management, but KUB chicken had the potential to be developed as an egg and meat producer in Indramayu Regency.
\end{abstract}

Keywords: BEKERJA Program; Diversity at the beginning of egg-laying chicken; KUB chicken

\section{Abstrak}

Kajian bertujuan untuk mengetahui keragaman ayam KUB yang dipelihara oleh RTM di Kabupaten Indramayu dalam pelaksanaan program BEKERJA tahun 2019. Program BEKERJA melibatkan 8.189 RTM dengan memberikan bantuan 50 ekor DOC ayam KUB, pakan selama 5 minggu pemeliharaan, bantuan sarana prasarana pemeliharaan meliputi tray tempat pakan, botol tempat minum, kandang brooder, kabel, lampu, dan bantuan subsidi kandang untuk ayam umur 4 minggu. Parameter yang diamati adalah jumlah kematian ayam, umur bertelur pertama kali dan produksi telur pertama kali. Hasil pengamatan menunjukkan bahwa kematian ayam KUB meningkat pada 3 bulan usia pemeliharaan, yang disebabkan oleh penjualan dan pemotongan ayam serta kematian akibat manajemen pemeliharaan yang kurang tepat. Jumlah produksi telur pertama kali di Kecamatan Anjatan dan Kecamatan Bongas masing-masing sebesar 7.066 butir dan 1.041 butir. Hasil kajian menunjukkan adanya keragaman pada awal bertelur ayam yang diakibatkan oleh manajemen pemberian pakan yang tidak tepat, namun ayam KUB berpotensi dikembangkan sebagai penghasil telur dan daging di kabupaten Indramayu.

Kata kunci : Ayam KUB; Keragaman awal bertelur; Program BEKERJA 


\section{PENDAHULUAN}

Indonesia merupakan negara yang memiliki keanekaragaman hayati yang tinggi, sehingga menempatkan indonesia sebagai negara yang memiliki keanekaragaman genetik yang luas. Melimpahnya keanekaragaman genetik tersebut mendukung riset-riset untuk pemuliaan, terutama untuk peternakan sehingga mampu menciptakan rumpun baru dengan sifat unggul. Salah satu sumberdaya genetik peternakan yang dimilik oleh Indonesia adalah ayam lokal. Ayam lokal tersebut memiliki sifatsifat unggul yang bisa dimanfaatkan, baik dari segi pemenuhan kebutuhan pangan, sebagai ayam hias dan sebagai ayam yang menghasilkan suara yang banyak dilombakan. Persilangan genetik banyak digunakan untuk memperoleh rumpun ayam lokal yang memiliki sifat-sifat yang lebih unggul dari tetuanya. Munculnya sifat unggul yang lebih baik tersebut memberikan manfaat kepada masyarakat. Pemanfaatan ayam lokal sebagai salah satu sumber penghasil protein hewani dapat meningkatkan taraf hidup masyarakat pedesaan (Nataamijaya, 2017).

Pengentasan kemiskinan merupakan salah satu program nasional yang dicanangkan oleh pemerintah pusat, dalam bentuk Program Bedah Kemiskinan Rakyat Sejahtera (BEKERJA) berupa program strategis yang diluncurkan oleh Kementerian Pertanian bertujuan untuk mendiseminasikan hasil penelitian bibit unggul ayam lokal yang diharapkan dapat meningkatkan tingkat pendapatan rumah tangga miskin (RTM) peternak. Penetapan RTM peternak tersebut berdasarkan data dari Keputusan Menteri Sosial Nomor 57 Tahun 2017 tentang Penetapan Data Terpadu Program Penanganan Fakir Miskin di Kabupaten Indramayu, Provinsi Jawa Barat. Ayam kampung unggul Balitbangtan (ayam KUB) merupakan ayam lokal hasil persilangan genetik yang dilaksanakan oleh Balai Penelitian Ternak Ciawi. Pada tahun 2019, Badan Litbang Pertanian mendiseminasikan ayam KUB kepada RTM peternak yang dilaksanakan di 3 kecamatan di kabupaten Indramayu, Provinsi Jawa Barat.

Ayam KUB memiliki sifat genetis yang lebih baik bila dibandingkan dengan ayam kampung biasa (Hidayat et al., 2011).
Pelepasan galur ayam KUB-1 berdasarkan Surat Keputusan Menteri Pertanian Republik Indonesia Nomor : 274/Kpts/SR.120/2/2014. Ayam KUB memiliki sifat bertelur yang tinggi dan seragam. Ayam KUB memiliki produksi telur sebesar 160 - 180 butir/tahun, produksi telur henday sebesar $50 \%$, puncak produksi telur henday $65-70 \%$ dan umur pertama bertelur sekitar 20 - 22 minggu. Peluang usaha dari ayam KUB masih terbuka lebar, melalui pemanfaatan daging dan telur yang dapat diupayakan melalui pengembangan ayam KUB (Prawiranegara et al., 2018). Ayam KUB yang didstribusikan dalam Program BEKERJA dapat dipelihara dengan baik dan dimanfaatkan secara maksimal RTM peternak yang mendapatkan bantuan diharapkan dapat membantu meningkatkan taraf hidup.

Tujuan dari kajian ini adalah untuk memperoleh informasi mengenai profil dan keragaman ayam KUB yang dipelihara oleh RTM peternak di Kabupaten Indramayu pada pelaksanaan program BEKERJA tahun 2019.

\section{METODE PENELITIAN}

Program BEKERJA yang dilaksanakan di kabupaten Indramayu pada tahun 2019 terdiri dari 31 desa, meliputi 10 desa di Kecamatan Haurgeulis, 13 desa di Kecamatan Anjatan, dan 8 desa di Kecamatan Bongas, dengan jumlah total 8.189 RTM. Distribusi bantuan ayam KUB dan pakan ke masing-masing lokasi dilakukan secara bertahap mulai bulan Maret 2019 sesuai jadwal pengiriman ayam dari kandang penetasan.

Kegiatan

program

BEKERJA

dilaksanakan melalui 1) pelaksanaan bimbingan teknis kepada RTM penerima bantuan; 2) pemberian bantuan DOC ayam KUB sejumlah 50 ekor, pakan, kandang brooder untuk pemeliharaan awal, kabel, lampu, tray tempat pakan, tempat minum dan bantuan subsidi kandang untuk ayam mulai umur 4 minggu. Pakan yang diberikan selama 5 minggu merupakan pakan pabrikan yang berbentuk crumble dengan kisaran kandungan protein kasar sebesar 17\%. Kandungan proksimat pakan bantuan diperoleh dengan analisis laboratorium. Bantuan vaksin, vitamin dan obat-obatan diberikan melalui dokter 
hewan dari dinas setempat dengan jadwal yang telah ditentukan.

Metode pengambilan data lapangan dilakukan sampai dengan 4 minggu pemeliharaan setelah ayam diterima oleh RTM sesuai jadwal yang telah ditentukan. Pengamatan data menggunakan data mingguan populasi ayam KUB yang dikirimkan oleh Pendamping Desa dalam bentuk excel. Data yang diamati antara lain data populasi ayam (ekor), mortalitas ayam (ekor), dan data produksi telur awal (butir). Data yang diperoleh kemudian dianalisis secara deskriptif.

\section{HASIL DAN PEMBAHASAN}

\section{PROFIL RTM DI LOKASI PELAKSANAAN PROGRAM BEKERJA KABUPATEN INDRAMAYU}

Sebagian besar penduduk di lokasi pelaksanaan program BEKERJA Kabupaten Indramayu bekerja sebagai petani yang mengusahakan tanah pertanian atau menunggu pekerjaan berikutnya (menunggu panen atau saat musim hujan). Kepemilikan lahan juga menjadi salah satu syarat dalam memelihara ayam KUB. Menurut Badan Pusat Statistik Kabupaten Indramayu (2018), presentase rumah tangga miskin menurut penguasaan lahan bangunan tempat tinggal yaitu kategori milik sendiri sebesar 76,22\%, kategori bebas sewa sebesar 20,66\%, dan kategori lain-lain sebesar $3,12 \%$. Secara umum, populasi ayam lokal yang ada di Kabupaten Indramayu pada tahun 2018 sebesar 1.757.547 ekor (BPS Jawa Barat, 2019).

Data RTM peternak sebagai target kegiatan diperoleh dari Keputusan Menteri Sosial Nomor 57 Tahun 2017 tentang Penetapan Data Terpadu Program Penanganan Fakir Miskin Kabupaten Indramayu, Provinsi Jawa Barat. Jumlah RTM peternak di 3 kecamatan di Kabupaten Indramayu dapat dilihat pada Gambar 1.

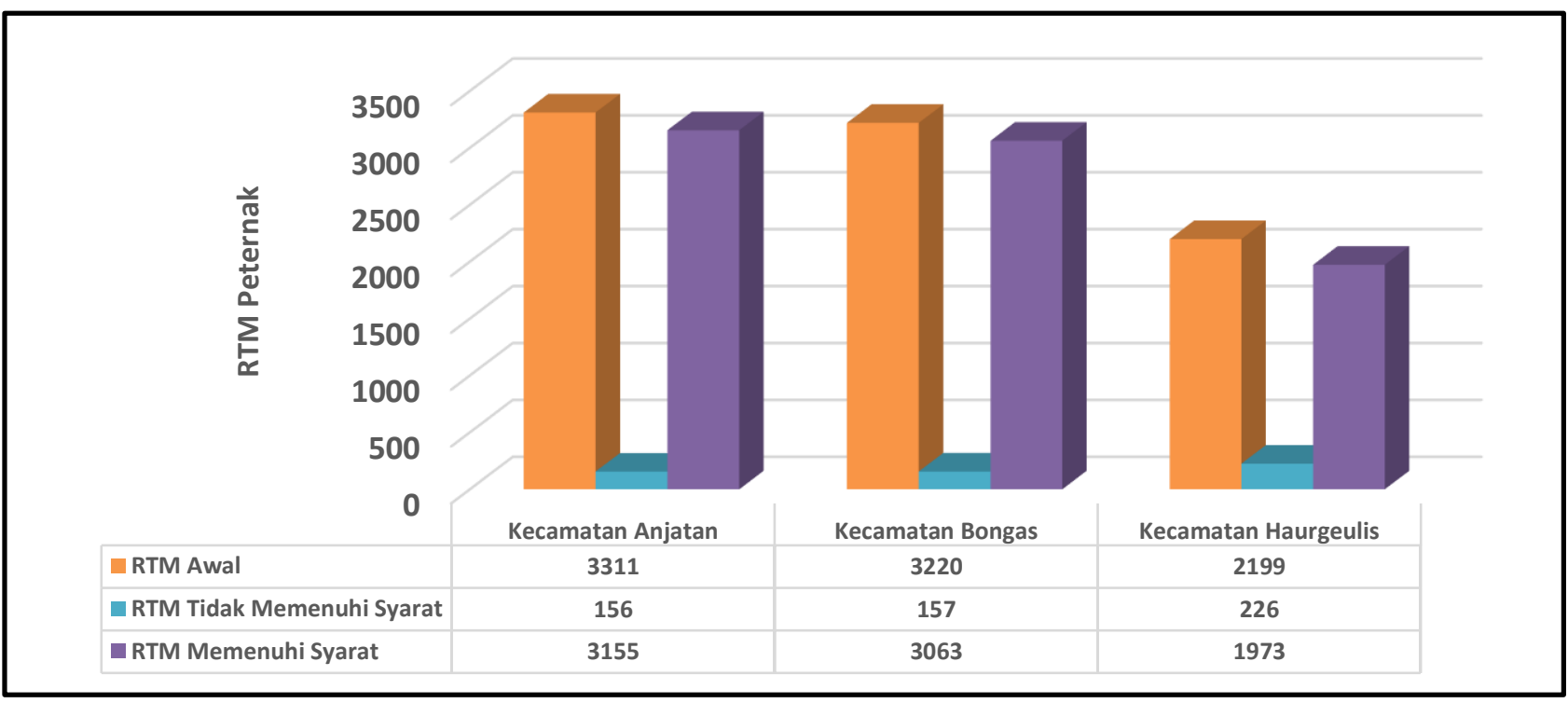

Gambar 1. Grafik Rekapitulasi RTM di Lokasi Pelaksanaan Program BEKERJA Kabupaten Indramayu

Pelaksanaan program BEKERJA dimulai dari penentuan RTM peternak melalui proses verifikasi on desk dan lapang. Kriteria yang digunakan sebagai penentuan RTM peternak yang layak mendapatkan bantuan antara lain a) memiliki latar belakang pekerjaan di bidang pertanian/peternakan; b) memiliki lahan yang cukup untuk memelihara bantuan ayam lokal unggul; c) bersedia memelihara ternak ayam lokal unggul. Berdasarkan Gambar 1 di atas,
RTM di 3 kecamatan di Kabupaten Indramayu yang memenuhi kriteria sebagai RTM peternak sebanyak 8.191 RTM, sedangkan RTM yang tidak memenuhi kriteria sebesar 539 RTM. RTM yang tidak memenuhi kriteria antara lain RTM sudah dinyatakan mampu secara ekonomi, pindah domisili, bekerja di luar bidang pertanian, tidak mempunyai lahan untuk memelihara ayam, meninggal dunia dan tidak mempunyai ahli waris, dan alasan lain seperti 
tidak bersedia dan pikun/menderita sakit. Faktor internal dalam pemelihaaan ayam KUB seperti RTM berpengaruh terhadap perkembangan ternak ayam KUB di masyarakat (Prawiranegara et al., 2018).

\section{GAMBARAN POPULASI AYAM KUB YANG DIPELIHARA OLEH RTM DI KABUPATEN INDRAMAYU}

Profil ayam KUB yang dipelihara oleh RTM di kabupaten Indramayu pada tahun 2019 dapat dilihat pada Gambar 2.

Dari Gambar 2, diketahui bahwa penurunan jumlah populasi ayam KUB terjadi pada bulan ketiga masa pemeliharaan, yaitu di kecamatan Anjatan mengalami penurunan yang cukup signifikan dimulai pada bulan Mei, sedangkan penurunan populasi ayam KUB di kecamatan Bongas dan Haurgeulis dimulai pada bulan Oktober. Hal ini terjadi karena umur ayam yang memasuki 10 minggu sudah masuk umur yang cukup untuk dikonsumsi maupun dijual. Kebanyakan peternak memanfaatkan ayam KUB yang dipelihara untuk dikonsumsi maupun dijual pada saat perayaan hari besar Idul Fitri. Hasnely et al. (2017) menyebutkan bahwa ayam kampung pada umur 10 minggu dapat memiliki bobot sebesar $300 \mathrm{~g}$ (betina) $1300 \mathrm{~g}$ (jantan).

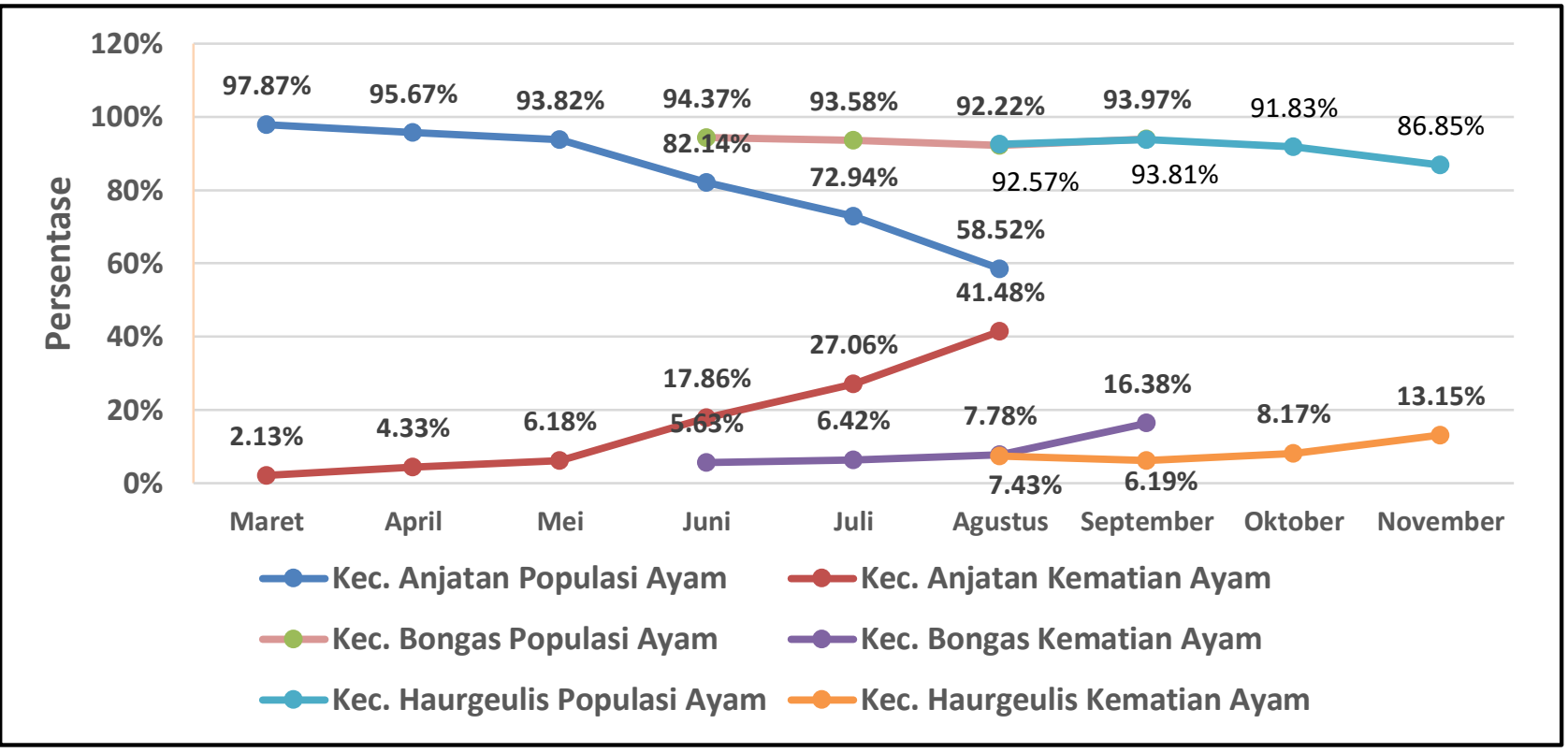

Gambar 2. Grafik Populasi Ayam KUB yang Dipelihara oleh RTM di Kabupaten Indramayu

Penyebab lain dari kematian ayam KUB pada umur 3 bulan pemeliharaan adalah kurangnya pemahaman para peternak mengenai pemeliharaan dan sanitasi kandang. Sanitasi kandang yang buruk dapat menyebabkan munculnya berbagai macam penyakit dan dapat mengakibatkan kematian. Jumlah ayam yang melebihi kapasitas kandang juga dapat menyebabkan stres pada ayam. Hal tersebut dapat mempengaruhi performa ayam, bahkan dapat menyebabkan kematian. Menurut Zainal dan Triwardhana (2014), perbaikan sanitasi dan manajemen perkandangan merupakan hal yang sangat penting untuk menunjang keberhasilan pemeliharaan ayam.
3. Produksi Telur Pada Umur Bertelur Pertama Ayam KUB di Kabupaten Indramayu

Jumlah produksi telur pada umur bertelur pertama ayam KUB di Kabupaten Indramayu dapat dilihat pada Tabel 1.

Ayam KUB merupakan galur ayam petelur unggul hasil seleksi dengan keunggulan produksi telur yang tinggi. Ayam KUB juga memiliki sifat mengeram yang rendah sehingga cocok untuk dijadikan sebagai ayam petelur yang memiliki puncak produksi sebesar $65-$ $70 \%$ pada umur antara $30-35$ minggu (Sofjan, 2017). Dari Tabel 1, diketahui bahwa ayam KUB yang dipelihara oleh RTM di Kabupaten Indramayu mulai bertelur pada umur antara 143 - 148 hari. Umur bertelur pertama ayam KUB 
di lokasi pengamatan lebih cepat sekitar $7-12$ hari, hal ini menandakan bahwa kebutuhan nutrien ayam tersebut dapat dipenuhi dari pakan yang disediakan. Jumlah produksi telur pertama kali di Kecamatan Anjatan dan Kecamatan Bongas masing-masing sebesar 7.066 butir dan 1.041 butir, sedangkan ayam KUB yang dipelihara oleh RTM peternak di Kecamatan Haurgeulis belum menghasilkan telur (ayam muda). Hidayat et al. (2011) menyebutkan bahwa umur bertelur pertama kali ayam KUB betina pada umur sekitar 150 - 160 hari tergantung dari nutrisi pakan yang diberikan.

Tabel 1. Produksi telur awal ayam KUB yang dipelihara oleh RTM di Kabupaten Indramayu

\begin{tabular}{|c|c|c|c|c|c|}
\hline Desa/Kecamatan & $\begin{array}{c}\text { Distribusi DOC } \\
\text { Awal }\end{array}$ & Awal Bertelur & $\begin{array}{l}\text { Jumlah } \\
\text { Hari }\end{array}$ & $\begin{array}{c}\text { Protein } \\
\text { Pakan }(\%)\end{array}$ & $\begin{array}{l}\text { Produksi Telur } \\
\text { (Butir) }\end{array}$ \\
\hline $\begin{array}{l}\text { Desa Bugis - Kec. } \\
\text { Anjatan }\end{array}$ & 27 Februari 2019 & 20 Juli 2019 & 143 & 17 & 1794 \\
\hline $\begin{array}{l}\text { Desa Bugis Tua - Kec. } \\
\text { Anjatan }\end{array}$ & 01 Maret 2019 & 27 Juli 2019 & 148 & 17 & 4278 \\
\hline $\begin{array}{l}\text { Desa Anjatan - Kec. } \\
\text { Anjatan }\end{array}$ & 31 Mei 2019 & 25 Oktober 2019 & 147 & 17 & 994 \\
\hline $\begin{array}{l}\text { Desa Kertajaya - Kec. } \\
\text { Bongas }\end{array}$ & 13 Juli 2019 & 06 Desember 2019 & 146 & 17 & 1041 \\
\hline
\end{tabular}

Pemberian pakan dan kandungan protein pakan juga mempengaruhi waktu pertama kali bertelur. Program bantuan pakan di RTM kabupaten Indramayu menggunakan pakan ayam dengan kandungan protein kasar sebesar $17 \%$. Keragaman umur bertelur pertama kali ayam KUB di beberapa desa dalam satu kecamatan, dikarenakan sistem pemberian pakan oleh RTM yang tidak mengikuti petunjuk teknis pemeliharaan ayam KUB. Tingkat pengetahuan dan pemahaman peternak berpengaruh terhadap sistem pemeliharaan ayam KUB yang dilakukan sehari-hari (Adnyana et al., 2020). Peternak cenderung memberikan pakan dengan jumlah yang melebihi takaran per hari ke ayam KUB. Selain itu, peternak juga mencampur pakan yang sudah ada dengan bahan pakan alternatif lainnya yang belum diketahui nilai kandungan nutrisinya, sehingga dapat mengakibatkan perubahan nilai kandungan nutrisi pada pakan yang diberikan. Induk ayam KUB yang diberikan pakan dengan kandungan protein kasar yang baik, akan memiliki kinerja bertelur awal yang baik (Hidayat et al., 2011).

\section{KESIMPULAN}

Ayam KUB yang dipelihara oleh RTM di kabupaten Indramayu menunjukkan keragaman pada pertama kali bertelur, yang disebabkan oleh sistem pemberian pakan dan kandungan dari bahan alternatif pakan yang diberikan ke ayam KUB. Namun demikian, ayam KUB yang dipelihara di kabupaten Indramayu memiliki potensi sebagai penghasil telur dan daging yang dapat dimanfaatkan secara ekonomi oleh masyarakat, serta kajian lebih lanjut mengenai potensi bahan pakan lokal sebagai pakan alternatif dalam mendukung pengembangan ayam KUB di Kabupaten Indramayu.

\section{UCAPAN TERIMA KASIH}

Penulis mengucapkan terima kasih kepada penanggungjawab Program BEKERJA Puslitbangnak, Koordinator Lapangan, Tim Divisi Program BEKERJA, Koordinator Kecamatan, Pendamping Desa dan seluruh RTM Program BEKERJA tahun 2019 atas kerja keras dan kerjasama sehingga dapat terlaksana dengan baik.

\section{DAFTAR PUSTAKA}

Adnyana, I. P. C. P., Panjaitan, T., Astiti, L. G. S., dan Hipi, A. 2020. Analisis Keberlanjutan Program Pengentasan Kemiskinan Berbasis Bantuan Komoditas Ayam di NTB. SOCA: Jurnal Sosial Ekonomi Pertanian, 14(1), 88100. https://doi.org/https://doi.org/10.24843/S OCA.2020.v14.i01.p08 
Astiti, L.G.S., 2019. Profil Ayam KUB pada Rumah Tangga Miskin yang Terlibat pada Program BEKERJA Kabupaten Lombok Tengah Nusa Tenggara Barat. 733-737. Prosiding Seminar Nasional TPV 2019. https://doi.org/10.14334/pros.semnas.tpv2019-p.733-737

Badan Pusat Statistik Jawa Barat. 2018. Populasi Unggas Menurut Kabupaten/Kota dan Jenis Unggas di Provinsi Jawa Barat, 2018

Badan Pusat Statistik Kabupaten Indramayu. 2019. Presentase Rumah Tangga Miskin Menurut Status Penguasaan Bangunan Tempat Tinggal di Kabupaten Indramayu, 2018

Hidayat, C., Iskandar, S., dan Sartika, T. 2011. Respon Kinerja Perteluran Ayam Kampung Unggul Balitnak (KUB) Terhadap Perlakuan Protein Ransum Pada Masa Pertumbuhan. Jitv, 16(2), 83-89.

Iskandar S. 2017. Petunjuk Teknis Produksi Ayam pedaging Unggul (Program perbibitan tahun 2017). Bogor [ID] : Puslitbangnak

Nataamijaya, A. G. 2017. Pengembangan Potensi Ayam Lokal Untuk Menunjang Peningkatan Kesejahteraan Petani,, 29(4), 131-138. https://doi.org/10.21082/jp3.v29n4.2010.p 131-138

Prawiranegara, D., Liferdi dan Sunandar, B. 2018. Strategi Pengembangan Ayam KUB pada Program \#Bekerja di Kabupaten Garut Provinsi Jawa Barat. Creative Research Journal. Vol. 5, No 01 (2019. 4154.

Romjali, E., Hasinah, H., Pamungkas, F.A., dan Matondang, R. 2019. Kinerja Produksi dan Reproduksi Ayam KUB di Peternak Pembibit (Production and Reproduction Performance of KUB Chickens in Breeder Farmers). Prosiding Seminar Nasional Teknologi Peternakan Dan Veteriner 2019, 705-709.

Zainal, H. 2014. Crossbreeding pada Ayam Lokal untuk Meningkatkan Produksi Daging Satu Kilogram pada Umur 12 Minggu (Crossbreeding Program on Local Chicken to Produce One Kilogram Chicken Meat in 12 Weeks of Age). Prosiding Seminar Nasional Teknologi Peternakan Dan Veteriner 2014, 515-524.

Zainal. H., Iskandar, S., dan Sartika, T. 2018. Qualitative and quantitative characteristics of SenSi-1 Agrinak chicken. Jurnal Ilmu Ternak Dan Veteriner, 22(2), 68. https://doi.org/10.14334/jitv.v22i2.1605. 